\title{
SINA-KÕNETLUSED TÕNU ÕNNEPALU, ÜLO MATTHEUSE JA JAAN KAPLINSKI TEOSTES
}

\author{
BRITA MELTS
}

$\mathrm{T}$ õnu Õnnepalu luulelise mõttepäeviku „Kevad ja suvi ja” juhatab sisse lause: „Pühendan need ülestähendused tagantjärele Sinule” (Õnnepalu 2009a: 11). Niisuguses pühenduses ja sina poole pöördumises ei ole iseenesest midagi iseäralikku: paljud kirjandusteosed on austuse, tänulikkuse või millegi muu märgiks suunatud mõnele konkreetsele, enamasti lähedasele isikule ja lüüriline pöördumine on luuletraditsiooni osa. Ent Õnnepalu võtte muudab märkimisväärseks luulepäeviku lõpu eel tehtud retooriline pööre, millega väljendatakse sina-kuju kui eksplitsiitse adressaadi tähenduslikkuse tõusu: „Väikesed s-id mu kirjas Sulle / kasvasid Suureks” (Õnnepalu 2009a: 175). Edaspidi on pöördumine sinategelase poole juba pidev, lüüriline mina suhestub tema kirjade, tegemiste, mõtete jm-ga ning tunnistab, et „[k]õik hea tuleb mulle / nüüd Sinu käest” (Õnnepalu 2009a: 183). See tipneb dateeritud päevikust välja jääva avaldusega raamatu lõpus: „Seni kui mu armastus kestab, / ma kirjutan nüüd Sulle seda raamatut” (Õnnepalu 2009a: 191).

Enamgi, „Kevade ja suve ja” „tagantjärele Sinule” pühendamise ning teose lõppu sugeneva kõnetluse tähtsus ei piirdu üksnes selle luulepäevikuga. Mõni kuu hiljem ilmunud proosaraamatu „Paradiis” avang paneb väga selgelt paika teose eesmärgi ja raami:

Nüüd ma olengi siin, et kirjutada Sulle Paradiisist, ja mul on seitse päeva aega, nagu Jumalal oli maailma loomiseks, ja täna on esmaspäev ja laupäeva õhtuks ma pean olema oma jutustuse Sulle ära jutustanud, et ma võiksin hingata ja vaadata, et see hea on. [---] Ja ma sõitsin Sinust kaugele üle mere, et jutustada Sulle kõike seda, mis oli. Siin. Aga siis. (Õnnepalu 2009b: 7)

Sina poole pöördumine jätkub raamatus õige tihedalt ning paratamatult hakkab „Paradiisi” kirjutamisel silmas peetud adressaat sarnastuma luulepäevikus „Kevad ja suvi ja” kõnetatud sina-kujuga.

Õnnepalu võte kätkeb seega midagi enamat kui nii mõnigi teine konkreetsele „sinale” adresseeritud pala eesti kirjanduses, olgu siis Vaino Vahingu krestomaatiline jutustus „Sina” või Jaan Unduski kirjanduskaanonit dekonstrueeriv, „meie kultuurimetsade isahirve” poole pöörduv „Sina, Tuglas”. Neis mõlemas on narratiivse võtte eesmärgiks ennekõike vahendatava sina-kuju ilukirjanduslik visandamine. Õnnepalu tegeleb aga selgelt autobiograafilise minajutustaja esitamisega, eeskätt tema argise omailma kirjaliku (re)konstrueerimise ja läbivalgustamisega. Sealjuures ei saa sina, keda minajutustaja kõnetab, käsitleda pelgalt poeetilise üttena, sest teose käigus märgib Õnne- 
palu tegelane korduvalt, kuidas see, et ta peab jutustamisel silmas üht kindlat adressaati, määrab ühtlasi jutustamise viisi ja teose eesmärke. Õnnepalu minajutustaja kirjeldab oma suhet ühe kohaga kellelegi, kes on küll adressaadina paika pandud, ent kes on temast „kaugele üle mere” sõitmisega sihipäraselt seatud väljapoole minajutustaja aktiivset, igapäevast ruumi.

Sarnast võtet võib leida veel mõnest tänapäeva omaeluloolisest kirjandusteosest. Autobiograafilisse teksti kätketud adressaadiga suhestumist vaatlen artiklis peale Tõnu Õnnepalu „Paradiisi” veel kahe teose näitel, mille narratiivne eneseväljendus on suunatud ühele konkreetsele sina-kujule: Jaan Kaplinski „Isale” (2003), mis otsib dialoogi mitte kunagi kohatud ja ammu surnud isaga, ning Ülo Mattheuse „India armastus” (2006), mis sisaldab minajutustaja mitmekuise religioosse asüüli ajal armsamale saadetud kirju. Need kõik on autobiograafiateooria mõistes referentsiaalsed tekstid, milles soovitakse kontrollida ja „edasi anda informatsiooni tekstivälise „reaalsuse” kohta” (Lejeune 2010: 215), st nende üheks funktsiooniks on kujutada autorisarnase tegelase vahetut või ka minevikulist reaalsust; kirjeldus on suunatud kellelegi, kes on minajutustajast ruumiliselt eraldatud. Peale omaeluloolise momendi ja sinana fikseeritud adressaadi on kolme teose oluliseks ühisosaks seegi, et homodiegeetilise (kirjeldatavas maailmas ise tegelasena esineva) jutustaja mina avamise juures on väga oluline selleks valitud koht, mingi kindel keskkond, intiimselt tähenduslikuks kujunenud või alles kujunev maastik (Kaplinskil on selleks maakodu Mutiku, Mattheusel India). Seda kohta on esile tõstetud ka raamatule illustratsiooniks lisatud fotodega kas siis konkreetsetest objektidest ja inimestest või avaramatest maastikuvaadetest, kusjuures fotode kasutamine omakorda kehtestab autobiograafilisust (eriti Kaplinski ja Õnnepalu teostes). ${ }^{1}$ Seejuures ei ole tegu pelgalt argise ümbrusega, vaid loomingulist eraldumist võimaldava paigaga. See paik omandab ühtlasi kirjandusliku omailma tunnused, kuivõrd füüsilisest keskkonnast on loodud subjektiivsetel eelistustel ja valikutel põhinev kuvand. ${ }^{2}$

"Paradiis”, „Isale” ja „India armastus” on komponeeritud väga erinevalt: Õnnepalu on keskendunud isiklikult tähendusliku koha ajalisele ja ruumilisele avamisele, Mattheus pakub „enese loomise”, religioossete otsingute ning armastustunde kinnitamise lugu ja Kaplinski valgustab isaga suhestumise või isakuju (re)konstrueerimise raames lõike oma/jutustaja eluloost. Ühisosa - sina poole pöördumine, autobiograafilise teksti referentsiaalsus, ruumiline raam - on ometi piisav, et selle varal võrdlevalt vaadelda, mis on adressaadi, konkreetse sina-kuju roll nendes teostes. Mis tähendust kannab ta teoste kompositsioonis ja laadis? Milliseid tunnuseid, funktsioone, tähendusi kõnetatavale sinale omistatakse? Kuidas adressaadile mõtlemine mõjutab kirjanduslikku eneseesitust? Ning kas jutustus jääb siiski pigem endasse suletuks või muudab retooriline teise poole pöördumine selle vestluseks, milles väljendu-

\footnotetext{
${ }^{1}$ Fotode kasutamist geograafilise punkti kinnistajana Õnnepalu „Paradiisis” on käsitlenud Agnes Neier (2014: 47-54).

${ }^{2}$ Omailmne potentsiaal ning kõnetlusvõtte raamimine kindla kohaga on ühtlasi määrav asjaolu, mis eristab käesolevas artiklis analüüsitud teoseid niisugustest uusimatest omaeluloolistest sinale suunatud teostest nagu Andrei Hvostovi „Kirjad Maarale” (2019) ja Aija Sakova „Elamise julgus. Kirjad Käbile” (2019).
} 
vad ka teise hääl ja seisukohad? Samuti on huvikeskmes küsimus, kui palju avaneb niisugune kõnetlus mis tahes mõeldavale lugejale.

\section{Omaeluloolisus, adressaat, dialoogilisus}

Omaeluloolist kirjandust võib esmapilgul mõista monoloogilisena: vältimatult domineerib kirjutaja ühekõne, kes enesest lähtuvaid tegelikkuse kujutusi, selgitusi, (kaitse)reaktsioone ja egotsentrilisi vaatepunkte deklareerides justkui vaigistab diskussiooni „teistega” ning jätab endale viimase sõna (vt Martens 2016: 61-62). Selles mõttes avaneb kirjanduse enesestmõistetav dialoogilisus omaeluloolises teoses hillitsetumalt kui puhtfiktsionaalses kirjanduses. Teisalt on autobiograafilise teose üheks tähelepanuväärseks osaks ikkagi narratiivi suunatus kellelegi (vt Smith, Watson 2010: 88): enesest jutustades peetakse rohkem või vähem esiletulevalt silmas mingitki adressaati, mõttelist või tegelikku vastuvõtjat, kellest olenevad autobiograafilise mina avamise ja avaldumise viisid, minakuvandi struktuur, kontekstuaalne detailsus jms. Iga selgesti väljendatud mina tähendab nii või teisiti ka sina olemasolu, sest kuulavat vastandit eeldamata ei oleks mõtet määratledagi end minana - ja vastupidi, iga sina osutab ühtlasi kõnelevale minale, isegi kui see pole tekstis selgesti esil. Seega tähendab esimese ja teise isiku kasutamine paratamatult dialoogi, isegi kui vaid üks osaline räägib või kirjutab. (Burdorf 2017: 28) Lisaks mõjutab narratiivis esile toodud sina kui adressaat ka „passiivse kuulajana” (Schmid 2013) loo käiku, sest temaga suhestumiseks kasutatakse spetsiifilisi tekstuaalseid märke ja võtteid: minajutustaja avaldumise ja eneseanalüüsi vormid, eheduse ja avameelsuse kontekstualiseeritud märgid, retoorika, eluetappide kirjeldamise detailsus sõltuvalt silmas peetud vastuvõtja eeldatavatest teadmistest, pöördutavaga suhestumise tonaalsus jms. Nii on iseloomulik, et sinaga kirjanduslikult kõneldes ei kirjeldata tingimata adressaati kuigi täpselt, vaid lihtsalt märgitakse kontakti või suhet temaga ning just see suhtemuster tingib poeetilised ja retoorilised võtted, mille kaudu tuleb rohkem või vähem esile ka sina isiksus (Pawelec 2017: 320-321). Ühtlasi on sina otsekui kogemuslik taust, mis aitab jutustaval minal end määratleda ja moodustada (Pawelec 2017: 322).

Kuivõrd siinses artiklis on vaatluse all autobiograafilised teosed, on neis kujutatud tekstuaalne subjekt, minajutustaja ja empiiriline autor tugevas vastavuses. Seda kinnitavad autorile lähedastele inimestele ja tegelikele aegruumilistele detailidele osutamine ning muud üksikasjad, mis vastavad autori elufaktidele, näiteks kontaktid eri isikutega (vt Burdorf 2017: 26). Samamoodi võib igasuguse adresseerimisvõtte juures leida kõnetatava sina ja mõne autoriga lähedases kontaktis oleva isiku vastavusi, ent seejuures tuleb silmas pidada, et kirjanduslik sina kui konkreetne teoses esil olev adressaat ei ole olemas iseenesest, vaid moodustub alles teose käigus kas siis tema poole pöörduva subjekti kõnetlusega või ka lihtsalt mõne temale suunatud väljendiga (Pawelec 2017: 316-317; Burdorf 2017: 30). Niisiis võib eristada kaht üldist kategooriat: esiteks tekstiväline adressaat ehk tegelik lugeja; teiseks tekstisisene adressaat, keda autor on kirjutamisel silmas pidanud (Pawelec 2017: 314; Smith, Watson 2010: 89-90; Schmid 2013). Tekstisisese adressaadi 
juures tuleb omakorda eristada implitsiitset vastuvõtjat/lugejat ja eksplitsiitset ehk tekstis selgesti esitatud adressaati (Pawelec 2017: 314-315), kellele lüüriline lausuja või minajutustaja suunab oma sõnumi olgu otseste (sh grammatiliste) pöördumistega või vihjamisi, ent igal juhul ettekavatsetult - käesolevas artiklis ongi tähelepanu all just niisugune adressaat. Omaeluloolistes tekstides võib niisugune eksplitsiitne adressaat olla autobiograafilise mina kujuteldav, idealiseeritud ja puudu olev „teine”, keegi konkreetne lähedane (ka anonüümseks jääv) isik või mõnikord lihtsalt jutustaja minakuju varjus olev pool (nt päevikus) (Smith, Watson 2010: 87-89). Seega on huvitav vaadelda just autobiograafilise teose jutustaja ja adressaadi vahelist tingimatut suhestumist, suhtlemist ja vastastikmõju, kuna sellest sõltuvad muuhulgas tekstis avalduva tõe laad ja eneseavaldumise vormid. Ja kuivõrd autobiograafilises narratiivis eristatakse tegelikku või ajaloolist mina, jutustavat mina, jutustatud mina ja ideoloogilist mina (Smith, Watson 2010: 72), siis on oluline pöörata tähelepanu ka sellele, kuidas jutustaja ja adressaadi suhestumised on erineva mina-avalduse teenistuses.

Allpool vaadeldavad omaeluloolised kõnetlusaktid on otsesõnu suunatud tekstisiseselt konstrueeritud kindlale tegelasele, mitte tegelikule ega abstraktsele lugejale. Nende adressaat ei ole pelgalt kujuteldav või eeldatav vastuvõtja, vaid konkreetne, autoriga vastavuses olevale minajutustajale lähedane isik. Sina jääb enamasti aga vaikivaks tegelaseks ning neis teostes avaldub ennekõike suhtemuster, millele on erinevalt keelelisest suhtlusest iseloomulik see, et kõneleja ja kõnetatava rollid ei vahetu (Pawelec 2017: 315). Dialoog on seega loominguline - asümmeetriline või mittetäielik (Pawelec 2017: 315, 322 ) -, sest hoolimata omaeluloolisest alusest on teostes tegu n-ö jäljendatud, teeseldud või võimaliku suhtlussituatsiooniga (vt Burdorf 2017: 24; Pawelec 2017). Ilukirjanduslike taotlustega teostena jäävad need tegelike läkituste ja fiktiivsete kõnetluste vahealasse, kusjuures vestluste kujuteldavust võimendab kas siis kõnetaja ja kõnetatava füüsiline kaugus või ka surmast tingitud eraldatus. Ent pöördumine adressaadi poole kui eheda dialoogi tunnus (vt Martens 2016: 65) on kõikides teostes vägagi esil. Dialoogilisust tugevdab see, et adressaadiga läbivalt suhestumise, tema nii vormilise kui ka sisulise kõnetamise ja tema olemuse mingilgi viisil peegeldamise tulemusena kujuneb ka adressaat ise teose üheks tegelaskujuks.

Kuivõrd neis teostes on tähtis subjekti suhe sina kui kindla teise inimesega, olen käesolevas artiklis kasutanud pöördumisvõtte kohta sõna kõnetlus. Sellisel võttel on kahtlemata olemas ka mõned üleüldise lüürilise pöördumise ehk apostroofsuse tunnused: suunatus kellelegi teisele / millelegi muule kui tegelik või implitsiitne publik; eesmärk luua iseenda ja teise vahel suhe, mis aitab subjekti ennast moodustada poeetilisena; kalduvus öelda adressaadile midagi sellist, mida too arvatavasti juba teab (Culler 2015: 212, 216, 222, 225). Ent olen rõhuasetuse seadnud teoste autobiograafilisusele ega tõlgenda vaadeldavat võtet pelgalt ilukõnelise, abstraktse pöördumisena, vaid niisuguse eesmärgipärase suhtlusmustri konstrueerimisena, mida loo käigus ka esile tuuakse, ja autobiograafilise minajutustaja sisima vajaduse või sunnina kellegi konkreetsega vestelda. Apostroofi kasutav tekst erineb harilikust vestlusest selgemini, kusjuures adressaadilt võidakse poeetilise võttena paluda vastust, aga tekstis seda enamasti eksplitsiitselt ei kajastata (Culler 2015: 
237). Siin käsitletavates tekstides aga märgib minajutustaja aeg-ajalt ka (võimalikke) vastuseid oma kõnetlustele.

\section{Kõnetlus Paradiisist}

Õnnepalu teostes kõnetatav sina-kuju on käsitletavatest adressaatidest ainus, kelle seos minajutustajaga ei tule kohe alguses ühemõtteliselt esile - tema olemus selgub järk-järgult. Luulepäevikus „Kevad ja suvi ja” ei ole kindlale kaaslasele adresseeritus ja loo intiimne foon veel nii selge kui „Paradiisis”. Kuigi luulepäevikuski võib jälgida ühe kindla sinani jõudmise lugu, kinnistub adressaat alles siis, kui autorilähedane minajutustaja tõmbub sisemaalt (Esnast Järvamaal) saarelis-ääremaisesse pelgupaika, irdub oma argiümbrusest, võttes ette nädalase asüüli Paradiisina kujutatud Kalestes Hiiumaal. Kindlalt silmas peetud sina kaudu on minajutustaja piiranud nii jutustamise kestuse (seitsme päevaga lugu „Sinule” ära rääkida) kui ka kujutatava aja ja koha („kus ja millal asus see Paradiis, millest ma Sulle õieti rääkida tahan” (Õnnepalu 2009b: 8); „ma räägin ainult ühest ajast, mis oli see õige Paradiisi aeg” (Õnnepalu 2009b: 68)). Teoses on esiplaanil Paradiisi-nimelise subjektiivse omailma piiritlemine, määratlemine ja kehtestamine selleks valitud kujutuslaadis ning seda võibki pidada „Paradiisis” kasutatava kõnetlusvõtte esmaseks eesmärgiks. Õnnepalu on otsesõnu tunnistanud:

„Paradiis” on ühtepidi tõesti väga isiklik lugu. Ja ta on kirjutatud kellelegi. Tähendab, tema kirjutamise idee sündis soovist jutustada neid lugusid sellest ajast ja sellest paigast kellelegi, kes neid ei tundnud ja kellele ma väga tahtsin neid rääkida. Minu arust on see loomulik. Ikka ju on keegi, kellele sa kõigepealt tahad rääkida oma lugu. Sellest soovist ja jutustamisest sündis ühtlasi arusaamine, kuidas ma üldse tahan neid rääkida, või õieti, kuidas saab neid rääkida. Nii sündis lõpuks „Paradiis”. Ta on adresseeritud oma lugejale. (Õnnepalu 2010: 3)

Ehkki tsitaadi viimase lausega põimib Õnnepalu eksplitsiitse adressaadi ja kujuteldava lugeja, lähendades nõnda sina-kasutust üleüldisele poeetilisele pöördumisele, apostroofsusele, on teoses selgesti esil kindlale sinale suunatud jutustamine. Eksplitsiitne adressaat on mõjutanud tekstistrateegiat, seda, kuidas Paradiisist jutustatakse: narratiiv ei ole üles ehitatud niivõrd kronoloogiliselt, kuivõrd just kirjeldustega ühelt objektilt teisele liikudes, millega kaasnevad ka kerged emotsioonide või meelelaadi vaheldumised. Jutustuse mustri määrab aga see, et sinale kirjeldamiseks on valitud paiga niisugused omadused ja subjektiivselt tähenduslikud (maastiku)detailid, samuti mitmesuguseid seoseid loovad meeleolud, aistingud, mälestuspiltide rekonstrueerimist toetavad esemed, millest võrsuvad meelteilmingud võiks sobida kokku noore sõbra olemusega, st kuidagi huvitada sina, kelle poole pöördutakse, kellele oma lugu suunatakse. Kavatsuslikkusest, sihikindlast struktuurist annavad märku selgitused või hoiatusedki: „Aga Paradiisi loomadest ma tahan Sulle eraldi rääkida” (Õnnepalu 2009b: 29), „[---] sest hooneid oli Paradiisis palju ja nendest ma Sulle veel kirjutan" (Õnnepalu 2009b: 55) jne. 
Veelgi märgilisem on see, kuidas adressaadile mõtlemine on paika pannud teksti tonaalsuse ning omaeluloolise minategelase ilmnemise viisi. Nimelt on sina kui adressaadi peamine funktsioon olla k er g e vastuvõtja. Kui luulepäevikus mainib Õnnepalu, et luges „uue noore poeedi raamatut, / see tegi meele kergeks ja ajas une peale” (Ônnepalu 2009a: 165), siis „Paradiisis” saame näha, kuidas seesama kerge meel, selle alalhoid ja jagamine ongi jutustuse üheks kandejõuks ja eesmärgiks. Kindlapiirilist sina on jutustajale vaja olnud selleks, et temast eemal olles üks koht ja aeg endast välja kirjutada - mitte lihtsalt pihtimusena, vaid just kergelt, helgelt, nõnda, et kogu jutustus ja ka mälestused muutuksid sellest kergemaks. „Ja mul on Sulle jutustada nii kerge. Ma ei olekski varem sellega hakkama saanud. [---] Need on olnud asjad ja sellepärast kerged ja kui ma nad Sulle olen rääkinud, siis neid nagu enam polegi, nad on juba nii kerged” (Õnnepalu 2009b: 75); ,[---] mu hea ja armas sõber, kellele kerge on jutustada. Ja keda me vajame veel elus kui mitte seda, kellele kerge oleks jutustada asjadest, millest muidu on nii raske rääkida?" (Õnnepalu 2009b: 96)

Sellest edasi hargneb „Paradiisi” eksplitsiitse adressaadi järgmine tähendus. Kui neistsamadest Kaleste maastikest on Õnnepalu varem kirjutanud ambivalentsemalt, kaasates oma subjektiivsesse kohakuvandisse ka ebaõdusaid objekte ja tumedamaid meeleolusid, süngust, rõhuvat üksindust jne (nt „Harjutustes”, 2002), siis Paradiisi-loo suunamisega ühele kindlale vastuvõtjale pööratakse kohakuvand ümber, see muudetakse kirkamaks ja kergemaks kui varasemates mälestustes. Sina on jutustajale vaja selleks, et luua Paradiisi maastike kohale helge pühadusetunne ning et lugu suunaks soov vahendada üksnes positiivseid aspekte: „[---] ja mina tegelikult ei tahagi Sulle jutustada muud kui ainult head, sest ma ei mäletagi midagi muud Paradiisist" (Õnnepalu 2009b: 14). Ka autobiograafiline subjekt on sedapuhku võtnud helgema kuju: „Ma kirjutan, mis oli ja kes olid, ükskord Paradiisis. Ja ma tahan, et Su meel oleks sellest rõõmsam ja kergem, sest me ju lubasime teineteisele: me ei kurvasta enam" (Õnnepalu 2009b: 16). Sihipärasest helget seisundit edasiandvast jutustamisest on niisiis välistatud äng, rõhuvus, nukrus, sest nii on antud lubadus. Ja igaks juhuks teeb minajutustaja ka korrektiive võimalikus lugemismuljes, andmaks ette adressaadi lugemiskogemuse tonaalsuse: „Aga kui Sul jääb lugedes mulje, et mul on kahju nendest Paradiisi keldriaia liiliatest ja teistest lilledest, siis tegelikult see pole nii” (Õnnepalu 2009b: 82).

„Paradiisis” kõnetatud adressaat suunab seega jutustuse laadi ja tooni väga konkreetsel moel: ilma „Kevades ja suves ja” leitud sinata ei oleks olnud alust niisuguse loo niisugusel viisil jutustamiseks. Sellele vaatamata jääb sinategelane suures osas krüptiliseks, otsesõnu määratlemata ja positsioneerimata, olemuslikult avamata, karakteriks vormimata. Tema poole pöördutakse alati kui anonüümse sina poole ning minajutustaja nimetab teda lihtsalt oma nooreks sõbraks (nt Õnnepalu 2009b: 9), kelle hääl ja seisukohad jäävad teoses marginaalseks - domineerib jutustaja dotseeriv kõne, mis kaldub „dialoogilise narratiivse monoloogi" (vt Schmid 2013; Martens 2016: 65) poole. Samas juhatavad teoses esinevad vihjed kätte sinategelase tekstivälise konkretiseerimise võimaluse. Sellele ei ole aga „Paradiisi” retseptsioonis, mis üldjuhul on sina-kõnetlustest mööda vaadanud, erilist tähelepanu pööratud. Põgusalt on nimetatud raamatut kiriromaaniks, osutatud Teise kui oodatu motiivile ning 
märgatud, et „paradiisi ei saaks eksisteerida selleta, kellele paradiisimaailmast (armastusega ja armastusest) jutustada" (Talivee, Tüür 2012: 1295, 1300, 1305). Üksnes Mart Velsker on täheldanud „Paradiisis” leiduvaid jälgi, „mis teevad nimedeni jõudmise võimalikuks”, jättes aga eksplitsiitse adressaadi delikaatselt täpsustamata (Velsker 2010: 172). Tema jaoks on tähtsam asjaolu, et „Õnnepalul on kindel soov sellest [kohast] rääkida ja ta tunneb, et on ka keegi, kellele rääkida", ja et niisugust jutustust on päriselt vaja (Velsker 2010: 173).

Ometi on see, kellele lugu jutustatakse, just sisuliselt oluline ja sina-kuju on kokkuvõttes selgelt määratletav. Näiteks kõnetab Õnnepalu sinategelast kui noort sõpra, „kes sa praegusel tunnil võib-olla alles magad magusat und seal kaugel mere ja maa taga oma pööningutoas, mille tapeedile Sa väga noore poisina ennast otsides maalisid suletud silmadega Ferdinandi" (Õnnepalu 2009b: 9). Teisal antakse Paradiisi poolt vaadates mere ja maa taga asuvale pööningutoale veidi täpsem asukoht: „Nüüd on päike muidugi juba üleval metsa kohal, Sina magad küllap seal oma pööningukambris veel magusat und ja päike paistab üle Peipsi ka sinna sisse" (Õnnepalu 2009b: 154). See ja ka järgmine tekstikatke - „Soojus on õhus. Sulle see on sisemaal tavaline asi, aga siin Paradiisis on see maikuu viimase päeva kohta haruldane nähtus" (Ỗnnepalu 2009b: 172) - on ühtlasi näited sellest, kuidas Õnnepalu minajutustaja seob oma olevikulise kogemuse, aistilised maastikud teose adressaadi hetkeolevikuga. Nii loob ta teatud mõttes maastikulise dialoogi, kuna tegu on kahe kirjandusliku omailma suhestumisega, ja see asjaolu saavutatakse just kõnetlusvõttega. „Paradiisi” sina-kujus võib nimelt ära tunda Andrus Kasemaa loodud Poeedirahu kui kirjandusliku omailma ${ }^{3}$ subjekti, mida eriti toetab üks konkreetne, nähtava tekstidevahelise kahekõne tekitav vihje lammastest ja raamatutest: „Sest [raamatuid] ära visata, taha õue hunnikusse viia, lammastele närida, nagu Sina tegid, seda inimesed enamasti ei raatsi" (Õnnepalu 2009b: 15). Onnepalu osutab sellega Kasemaa Poeedirahu-nimelises blogis 2009. aasta kevadel („Paradiisi” kirjutamisele veidi eelnenud ajal), seejärel kogumikus „Raamat” (2009) ning luulekogus „Kustutamatud õhtud” ilmunud luuletusele: „Viskasin päeval raamatuid aknast välja / ei mahtunud enam tuppa ära / lambad nätsutasid neid natuke / aga üldiselt / lammastele ei maitse raamatud" (Kasemaa 2012: 40). Kahe omailma suhestumine tuleb nähtavale muudestki asjaoludest: poeetilis-subjektiivsest Paradiisist jutustamise ajal võis Poeedirahu-blogis peale lammastele raamatute söötmise luuletuse kohata näiteks Õnnepalu teoses nimetatud Ferdinandi pilte; Poeedirahu kui omailma põhiiseloomustajate hulka kuuluvad Peipsi ja rõhutatult sügav sisemaa, aga leida võib ka pööningu(toa) märkimisi. Nõnda on „Paradiisi” minajutustaja sina poole pöördudes osutanud elementidele, mis ühel või teisel viisil iseloomustavad tollal kirjandusliku omailmana alles kuju võtvat Poeedirahu ja seega ei kõneta niisugusel kujul mis tahes mõeldavat vastuvõtjat, vaid just Poeedirahu subjekti. Seetõttu ei jää sina poole pöördumised pelgaks ühekõneks, vaid annavad aimu ka sina-kuju subjektsusest ja teatud seikade

${ }^{3}$ Fiktiivse toponüümiga tähistatud Poeedirahu kui kirjandusliku omailma kujundamine sai alguse Kasemaa 2008. aastal ilmunud debüütluulekogus „Poeedirahu” ja kulmineerus proosateoses „Leskede kadunud maailm” (2012). 
märkimises (sinaga telefonitsi vestlemine või kirjavahetus) tuleb kokkuvõttes esile koguni sinategelase agentsus.

Sellega, et „Paradiisi” adressaadis võib ära tunda Poeedirahu subjekti, kitsendab Õnnepalu seda adressaati, st annab talle piiritletavama kuju, ja samal ajal suurendab sina-kuju tähendust „Paradiisi” jaoks. Hoolimata sellest, et Poeedirahu subjekt osutub adressaadi rollis ennekõike passiivseks vastuvõtjaks, põimub teoses väljendatud sinategelase vajamine jutustaja iseenda pihtimise vajadusega nõnda, et teisele kirjutamine aitab mõtetes ja arusaamades jõuda ühtlasi temale lähemale: „Jutustades oma Paradiisist olen ma endale märkamatult jutustanud Sinust" (Õnnepalu 2009b: 169). Enamgi, lüürilisidüllilise Poeedirahu subjektiga suhestumine annab „Paradiisi” minajutustajale võimaluse peegeldada teise kaudu iseennast ja üht tähenduslikku kohta nõnda, et ta saab tasahaaval püüda justkui selle mõjust vabaneda, kirjutamise kaudu sellest lahti lasta (,võibolla ma ainult kirjutangi sellepärast Sulle sellest kõigest, et temast lahti lasta" (Õnnepalu 2009b: 37)). Selle tulemuseks ongi varasema kohakogemuse ja minevikuliste meeltemaastike ümbermängimine. Seega võib Õnnepalu adresseerimisvõttes näha ühe aegruumi sulgemist ja uue kujundamist vastavalt subjektiivsetele eelistustele, valikutele ja vajadustele (selle kohta pikemalt vt Melts 2014). Lõpuks suudab minajutustaja näha oma jutustuses ka teraapilist funktsiooni: „[---] ja seda lugu jutustan ma samuti Sulle. Aga natukene ka endale. Sinu kaudu endale. Sest jutustamine võtab ära sellegi salajase valu ja kahetsuse, mis veel südamepõhja on jäänud. [---] Aga lugu on juba lugu, see ei tee enam kellelegi haiget. Või kui teeb, on see magus valu, kerge valu, mis hinge terveks ravib." (Õnnepalu 2009b: 162)

Nõnda võib „Paradiisis” sinana kõnetatava adressaadi kohta kokkuvõtvalt öelda, et ehkki tema piirid, meelelaad, suhtumised, vastukajad jäävad krüptiliseks (vihjete või põgusate fraasidega on „Paradiisis” osutatud millelegi, mille tähendust teab või mida on kogenud üksnes kõnetatav sina-kuju), on tema olemus kahe omailma suhestumise kaudu selgesti raami võetud, kujuteldavalt paigas ning ta on süžeega kaudselt seotud. Teda ei annaks sujuvalt asendada mis tahes mõeldava vastuvõtja või mudellugejaga.

\section{Kõnetlus Indiast}

Epistolaarse romaani ${ }^{4}$ „India armastus” minajutustaja püstitab avaleheküljel küsimused: „Mis on elu mõte? Mis on olemise mõte? Mida ma peaksin oma eluga tegema?" (Mattheus 2006: 11) Nende põhjal oleks kirjutamisel justkui kaks sihti: esiteks üldfilosoofiliste küsimuste üle arutlemine, teiseks ja ennekõike eneses selgusele jõudmine. Ometi annab minajutustaja sealsamas endale aru, et küsimustele vastust ei ole ning nende pideva esitamise põhjus on ebakindlus, kahtlemine või „koguni äkiline segadus”. Niisiis on autobiograafiline minajutustaja võtnud ette meditatiivse, koguni solipsistliku rännaku, selleks et mõtestada nii oma tundeid, eriti armastust, oma meeleseisundeid ja sisemist segadust - iseennast, kelle eest ta on „rumalal kombel põgenenud”

${ }^{4}$ Teost on lisaks kiriromaanile nimetatud ka reisikirjaks, mõtte- ja tundepäevikuks, mille „sekka põimitud india legende ja muinasjutte” (Lindsalu 2006). 
(Mattheus 2006: 11) - kui ka religioosseid otsinguid ja veendumusi. Nõnda on laias laastus tegu iseendas selgusele jõudmise looga. Ehkki lõppsiht ei tundugi olevat oluline (vastuseid leida on võimatu), on tähtis sellest kõigest kirjutada. Kuna minajutustaja eneseotsing on adresseeritud tema armastatule, ${ }^{5}$ on lugu ka suhtlemisakt, mille käigus suhestub jutustaja ühtlasi adressaadi vastustega neid põgusalt refereerides või neile osutades.

Niisiis ei ole siin sinale jutustamisel nii selget eesmärki nagu Õnnepalul: üks konkreetne lugu kindlate päevade jooksul kellelegi ära rääkida. Ka ei ole Mattheuse teksti kulg sedavõrd määratud kui „Paradiisis”, vaid selle struktuur on spontaansem ja hajusam - mina annab erinevatest seisunditest, mõtetest ja n-ö tekstivälisest reaalsusest aru osalt just suhtlemise eesmärgil. Teose alapealkiri „Fragmendid kirjadest” ja kuupäevastatud teadaanded näitavad, et raamat ei ole kirjutatud sisemonoloogilise päevikuna, vaid dialoogi üritavate kirjadena. Kui Õnnepalul on algusest peale selge olnud, mida ja kuidas sinale jutustada, st milliste objektide ja meelelaadi kaudu oma lüürilist adressaati kõnetada, ning sina vastukaja ei ole tema narratiivi eesmärgipärast struktuuri kõigutanud (ehkki on mõjutanud tonaalsust), siis Mattheuse lool niisugune ette paika pandud ja kinnipidamist nõudev ülesehitus puudub. Tema jutustuse fragmendid, kuude kaupa grupeeritud ja kuupäevaliselt nummerdatud, algavad sageli minajutustaja emotsionaalse reaktsiooniga saadud kirjale (nt „Armas kallis, on nii südantsoojendav lugeda su kirju siin kaugel võõral maal” (Mattheus 2006: 108); „Su tänane kiri oli väga armas ja jättis minusse sooja tunde" (Mattheus 2006: 150)) ja tihtipeale on adressaadilt saadud kirja sisu omakorda mõjutanud seda, mida minajutustaja kajastab ja kuidas ta seda teeb. Näiteks teatele, et armsama „viimane kiri rahustas mind ja tegi õnnelikuks, ja kohe unustasin end ka poodi kirjanduse keskele mõnulema” (Mattheus 2006: 51), järgneb kergemas, tasakaalustatud meeleolus ekskurss budistlikku kirjavarasse. Või siis tagasisidestades, et „Su viimane kiri oli nii ilus ja erutav" (Mattheus 2006: 56), võtab minajutustajagi spontaanselt sõna kehalise läheduse, selle igatsuse teemal, püüdes oma iha kirjutamise kaudu ka taltsutada.

Kuigi minajutustaja ei avalda ega tsiteeri temale saadetud kirju, osutab ta neile siiski pidevalt ning aeg-ajalt ka peegeldab neid vähesel määral - Mattheuse minajutustaja astub kujutatava sinaga kaudsesse dialoogi (nt fraasid, nagu „Mõtle, Armsake, et” (Mattheus 2006: 49), „Sa ütlesid, et” (Mattheus 2006: 193) või väitlusse juhatav algus kirjas „Väitsid, et” (Mattheus 2006: 184)). Samuti on silmas peetud adressaadi tegevusi kodumaal: sinategelane kirjutab doktoritööd ning minajutustaja püüab seda ettevõtmist turgutada, jagades vastavaid nõuandeid (Mattheus 2006: 88-89), aga ka rääkides sellest, kuidas budistlikust seisukohast on teadus „üks mina-teadvuse liike" ja seepärast vältimatult subjektiivne (Mattheus 2006: 44), misjärel peab

\footnotetext{
${ }^{5}$ Õieti on raamatus esil kaks adressaati: põhiosa, armsamale suunatud kõnetlused vahelduvad kursiivkirjas pöördumistega ühe buda munga poole. Ent kuna munga poole pöörduvad fragmendid jäävad tugevamini sisemonoloogiliseks, iseendast lähtuvaks ja iseendale orienteerituks kui kirja vormis kõnetlused, st mungale suunatud kirjakohad on niisugused retoorilised pöördumised, mis ei ava võimalusi adressaadi vastukajale ega eeldagi seda, keskendun antud juhul „armsakese” poole kirja vormis pöördumistele, mis on eksplitsiitselt mõjutanud ennekõike kirjutust, mitte minajutustaja enesevaatlust.
} 
minajutustaja vajalikuks justkui sammukese tagasi astuda: „Armsake, olin vist liiga filosoofiline, kuid üritan edaspidi reaalsusesse tagasi tulla [---]. Ma loodan, et eelnev jutt ei vähenda sinu indu oma doktoritööd teha, vaatamata teaduse tegemise illusoorsusele." (Mattheus 2006: 45) Seega arvestab Mattheuse tegelane oma partneriga pidevalt, jutustuse kulg ei ole ette paika pandud, selle määrab peale vahetu olustiku ja igapäevaste seikade just mõtteline suhtlemine partneriga.

Nõnda on Mattheuse teose adressaat konkreetsem kui Õnnepalu teksti ebamäärane, st üksnes põgusate vihjete kaudu kuju võttev (ehkki minajutustaja jaoks selgelt raamistatud) vastuvõtja. See juhtub suuresti tänu „India armastuses" kajastuvale suhtemustrile ja sina kaasamisele minajutustaja intiimse kogemusliku foonina. Kui „Paradiisi” minajutustaja jääb oma adressaadiga suhestumisel pigem registreerivale tasandile, mainides nt üksikuid detaile tema ümbrusest või põgusalt osutades teatud iseloomujoontele, siis Mattheuse tegelane mitte üksnes ei võta partneri häält kuulda, vaid laseb sel häälel ka tekstis põgusalt esile tulla ja vastab sellele häälele otseselt. Samuti suhestub ta oma adressaadi vahetu keskkonnaga - seda aga mitte maastikulise sillana (nagu Õnnepalul Paradiis vs. Poeedirahu), vaid enese- ja lähedustunde eesmärgil („Sinu kell Eestis on viis, minu oma siin pool üheksa. [---] Nii hea on tunda, et oled kuskil olemas ja mõtled mulle." (Mattheus 2006: 18)). Minajutustaja registreerib korduvalt tuhandete kilomeetrite pikkuse vahemaa (nt Mattheus 2006: 46, 96) ning ühtlasi teadvustab ja aktsepteerib lahusolekut, mis omakorda aitab üksindustunnet hajutada - andes sina-kõnetlusele omamoodi üksindusega lepitava funktsiooni.

Seega kui „Paradiisis” on jutustamise käigus põhjendatud adressaadi valikut otsesõnu sellega, et oleks keegi, kellele oma lugu kergesti ja helgelt ära rääkida ning nõnda vabaneda mingist minevikulisest paigapainest ja emotsionaalsest raskusest (aga mitte oma üksiolust), siis Mattheuse teoses on esmajoones tegu emotsioone esile kutsuva, armastust kinnitava ja kasvatava suhtlusega. Sina poole pöördutakse selgelt argielus vajaliku kommunikatsiooni eesmärgil. Ehkki suhtlus toimub distantsilt ja kirjatsi, on see pide ja vajadus, millest saada lohutust, armastust (Mattheus 2006: 31) või mis koguni aitab „ellu jääda ja mitte kurbusesse surra” (Mattheus 2006: 50). Suures osas visandab minajutustaja teda ümbritseva keskkonna olustikupilte ehk kontrollib ja jagab teavet samal ajal autorit ümbritsenud tekstivälise tegelikkuse kohta, mis on üks autobiograafilise teksti omadusi, nagu eespool osutatud (Lejeune 2010: 215). Sellel on aga peale tavapärase sidepidamise veel kaks eesmärki. Ühest küljest võimaldab adressaadi informeerimine minajutustaja vahetu elu lihtsatest pisiasjadest, kuna „neist ju elu koosnebki” (Mattheus 2006: 60), eemalolu kiuste lähedase inimese argielu rütmist ja mustrist osa saada. Teisest küljest aga vajab minajutustaja säärast eneseväljendust iseenda jaoks: troostitu räpasuse läbikirjutamine aitab tegelikku olukorda teadvustada nõnda, et tekiks õige häälestus harjumuspärasest niivõrd erineva ümbruse jaoks (vt Mattheus 2006: 70).

Samuti koorub niisugusest argisest kirjutamisest Mattheuselgi kui mitte päris sihipäraselt teraapiline nagu Õnnepalul, siis vähemasti pihtimuslik funktsioon. „India armastuse” minajutustaja jagab muu hulgas meeleheidet, rusuvat üksindust, valu ja pisaraid, tasakaalutust ja kõhklusi (nt Mattheus 
2006: 31, 45-46, 132, 147), mispeale loodab ta kirjatsi jõuda lohutuse, toe ja ehk koguni hingelise või emotsionaalse lunastuseni (vt Mattheus 2006: 86, 147). Nii on kirjutamine ja kindlale vastuvõtjale suunatus ühtlasi minajutustaja eneseesituse, tema sisemise tasakaalu, meeleseisundite stabiilsuse, loomulik olemise oskuse poole püüdlemise teenistuses (vt Mattheus 2006: 115). Seega on minajutustaja „enese loomine” (Mattheus 2006: 89) toetatud just eksplitsiitsele adressaadile, sinaga pidevale suhestumisele ja sinaga arvestamisele.

„India armastuse” eksplitsiitse adressaadi kõnetluse funktsiooniks võib seega pidada nii intiimset ja emotsionaalset suhtlust kui ka eksistentsiaalset kaemust, „enese loomist” eesmärgiga jõuda selgusele nii budistlikku õpetust kui ka armastustunnet puudutavates küsimustes. See on ühtaegu argine ja meditatiivne, enesekaemuslik dialoog lähedase, ent kaugel viibiva inimesega. Raamatu lõpuks naaseb minajutustaja armastatu juurde, olles ületanud varasemad emotsionaalsed kõhklused, õieti kahe suure armastuse - India armastuse (vt Mattheus 2006: 131) ja naise armastuse - binaarsuse. Minajutustaja veendumuseni armastuse kindlameelsuses ja õnnetundes on aidanud jõuda just mõttelise kõnetluse kaudu dialoogi loomine: oma vastavate arutlemiste, enesetaju ja tunnete peegeldamise suunamine iseendast väljapoole, oma armsamale lihtsa kommunikatsiooni eesmärgil.

Ent kui tegu on niivõrd intiimse dialoogiga - kõnelemisega küll „kultuurist ja usust ja olust, aga teadlikult ainult talle" (Raamatututvustus 2006) -, siis kas Mattheuse teos kõnetab ka mis tahes mõeldavat lugejat? Kuivõrd enesejutustamisel on keskne roll ühtlasi identiteedi loomisel (vt Kurvet-Käosaar 2017: 39), siis saab „India armastust” lugeda eksistentsiaalse arengu, mina üha põhjalikuma analüüsi ja sellest kasvava eneseloome romaanina. Krüptilisust on selles tegelikult vähemgi kui Paradiisist jutustamises, ning vahetu avalus annab teosele küllaltki tüüpilise pihtimusromaani raami.

\section{Kõnetlus Mutikult}

Jaan Kaplinski „Isale” algab konkreetse pöördumisega: „Ma olen kaua mõelnud ja kahelnud, kas ja kuidas sulle kirjutada" (Kaplinski 2003: 5) ja on žanrilt samavõrd piiripealne kui eelnimetatud. See on autobiograafiline eneseanalüüs (Salumets 2016: 35), esseistlik memuaar ja n-ö teispoolsusse läkitatud pihtimuslik kiri (Haug 2010: 236), poeetiline, epistolaarne pöördumine kirjaniku poola päritolu isa poole (Kurvet-Käosaar 2016: 171, 176). „Jah, see on mälestusteraamat, aga mitte ainult. Kaplinski on seal korraga nii pihtija kui ka perekonnabiograaf, nii filosoof kui ka kirjanik." (Hellerma 2004: 389) Mälestuslik ja kirjanduslik aspekt sarnastab seda rohkem „Paradiisiga”, pihtimuslik joon, eneseanalüüs ja filosoofilisus aga „India armastusega”. Ent perekonnaloo dokumenteerimisega seisab Kaplinski teistest eraldi ja ka tema adresseerimisvõte erineb tuntavalt, kuna jutustaja kõnetab kedagi, keda ta kunagi tundnud ei ole - oma elus puudunud isakuju. Jerzy Kaplinski arreteeriti 1941. aasta suvel, kui poeg Jaan oli vaid mõnekuune, ja saadeti Vjatlagi vangilaagrisse, kus ta 1943. aastal suri. Teose juured on niisiis sügaval Kaplinski lapsepõlves: sina poole pöördumise tõukejõuks on see, et minajutustaja 
ja ühe ta vanema vahel ei ole olnud suhtlust, teineteise ärakuulamist. Sellest on kasvanud sisemine vajadus kõnelda ellu tühiku jätnud isaga:

Aga kirjutan osalt just sellepärast, et sind ei ole, et ma ei ole saanud sinuga kunagi rääkida. Kirjutan sinule ka sellepärast, et ei oska kellelegi teisele niimoodi kirjutada kui sinule. Kirjutada sellest, mis on jäänud rääkimata, kuna mul ei ole olnud isa, kellega, kellele rääkida. Et olen nagu paljud teised, paljud isata kasvanud kahekümnenda sajandi kurja keskpaiga lapsed. Lapsed, kellel kõigil on jäänud midagi rääkimata, tundmata. Olemata. (Kaplinski 2003: 6)

Nii vormib Kaplinski kujuteldava dialoogi autobiograafilise jutustaja ja ta isa vahel. Ühelt poolt on siin eesmärk justkui sama selge nagu Õnnepalul: "Isale" minajutustaja tahab jagada oma suguvõsa uurimise tulemusi, päevikuliselt pihtida oma meeleseisundeist, samuti talletada oma perekonnalugu ehk kirjutada „kõigest, mis meie peres juhtus pärast sinu äraviimist, aga veel enam iseendast. Oma elust, oma perest, naisest, naistest, lastest, mõtetest, raamatutest. See raamat, need kirjad peaksid olema minu aruanne sinule, aruanne, mis tahes või tahtmata ootab heakskiitu või laitust." (Kaplinski 2003: 103) Teiselt poolt aga soodustab see, kuidas minajutustaja tunneb, et „peaks kirjutama kõigest”, ühtlasi kirjutise laialivalguvust ja täpse raami puudumist. "Isale” ei ole algusest peale paika pandud lõppsihiga narratiiv nagu „Paradiis” või konkreetsete ajaliste piiridega aruanne nagu „India armastus”, vaid hüpoteetilisele vastuvõtjale suunatud uuriv-arutlev jutustamine, mida juhivad sundimatult kerkivad küsimused, mõtteseosed, infokillud, mälusähvatused, probleemid, teadmissoovid, oletused, samuti kõhklused selles, mida ja mil viisil rääkida, kuidas oma elulugu avada ja lahendada avameelsuse dilemma (nt vakatused, nagu „Kummaline on sellest kirjutada” (Kaplinski 2003: 13)), jne. Teksti sundimatu ja otsinguline, kõhklusi registreeriv kulg on osalt sarnane Mattheuse raamatuga. Kaplinski jutustaja püüab oma looga samamoodi uurida iseenda isiksust, ent teeb seda laiemalt kui Mattheuse minategelane: oma elulugu üsna ülevaatlikult avades analüüsib ta oma komplekse ning otsib kõnetatavast sinast paralleele oma tunnetele, sarnasusi enda ja oma isa saatustes, vastuseid teda pikalt vaevanud küsimustele, näiteks milline peaks olema isa ja poja suhe. Kuna aga isiksuse ja elu kujunemisloole on antud mitte kunagi kohatud, vabalt kujutletud isaga peetava vestluse vorm, siis see välistab hariliku eluloo formaadi ja seab rõhuasetuse isa ja poja suhte konstruktsioonile. See annab autobiograafilisele intiimsusele ilukirjandusliku knihvi, täpselt nagu Õnnepalu ja Mattheuse teostes.

Ometi avaneb suuresti ettekujutustel põhineva isakuju poole pöördumises minajutustaja (ning ühtlasi empiirilise autori) elulugu terviklikumana kui Mattheuse või Õnnepalu teostes. Autobiograafiliste jutustuste üheks tunnusjooneks on see, et jutustajad kaasavad ühel või teisel viisil oma mäluarhiividesse ja osutustesse ka teisi, väliseid hääli, mis vältimatult mõjutavad autori häält või minajutustaja kui subjekti kujutust. Neid võib esitada näiteks dokumentide või dialoogide tsitaatidena, samuti kaudsete viidetena, ning ka silmas peetud adressaadi kaudu sugeneb autobiograafilisse teksti võõra hääl. (Smith, Watson 2010: 80-81) Nende häälte individualiseerituse määr mõjutab suuresti seda, kui intensiivselt ja neid arvestavalt suhestub nendega autobio- 
graafiline jutustaja ehk teisisõnu kui palju nad mõjutavad teksti kulgu. Õnnepalu jutustuse välised hääled markeerivad ennekõike kohta, millest ta soovib jutustada, vahendades näiteks pärimusi, mälestusi ja mõnel juhul ka kirju neil kõlada laskmine on jutustuse sihi teenistuses. Mattheusel toetavad teiste (budistliku munga, armsama) täheldused tema religioosseid ja emotsionaalseid otsinguid. Kaplinski on kasutanud aga märksa mitmekesisemaid allikaid: fotosid, raamatuid ja nendes olevaid isa allakriipsutusi, isa märkmeid ja kirju, perekonnalugusid, ajalookäsitlusi, kohtumisi isa tundnud inimeste ja sugulastega. Ent need detailid ei moodusta tema jaoks ühtset arusaama isast ja nõnda loob Kaplinski „isa portree, milles tõuseb esile [---] paratamatu, ent samas ka lohutust pakkuv kujutluslikkus, sest see on ainus, millele ta saab toetada oma isa loo" (Kurvet-Käosaar 2016: 171). Nii väliste häälte ja materjalide kaasamine kui ka ühtse portree toetamine kujutluslikkusele on kahtlemata põhjus, miks kõnetluse dialoogiline väljund jääb hajusaks ja raamatus „räägitakse isast kokkuvõttes vähe, peaasjalikult on jutt kirjutava mina suhtest isasse (mitte „temast” endast)” ning miks jutustaja minakesksus domineerib, ta avab teisi iseenda kaudu ehk iseend „teiste kiuste” (Tamm 2004: 108). Kõnetatava sina ehk isa tähendus kohati koguni tühjeneb (Hellerma 2004: 389) - või õieti jääb ta arvestatava suhtluspartneri asemel pigem lüüriliseks ütteks.

Nõnda võib ühest küljest pidada Kaplinski monoloogilisusse suubuvat kõnetlusvõtet luhtunuks, kui lähtuda sellest, et jutustaja väljendab ootust saada oma loole „tahes või tahtmata [---] heakskiitu või laitust” (Kaplinski 2003: 103): vastuvõtjani ju paratamatult ei jõuta, kõnetlused jäävad vastuseta ning eksplitsiitse adressaadi kuju jääb minajutustaja jaoks ikka ähmaseks, hoolimata selgesti väljendatud pöördumistest sina poole, ühtse arusaama otsinguist, isakuju rekonstruktsioonist, mõistmiskatseist. Teisest küljest aga on Kaplinski kõnetlusvõttes silmas peetud adressaadi ja teose tegeliku vastuvõtja lahknevus justkui kõige väiksem: ettekujutustele üles ehitatud eksplitsiitne adressaat, olgugi isaks nimetatud, on korraga omane ja võõras - ja „nii tema võõrus kui omasus on vaid oletatavad" (Pilv 2004), mistõttu võib sina kätkeda ühtaegu minajutustaja endale suunatud kõnetlust, nii ajalooliselt konkreetset kui ka mis tahes adressaati, mõeldavat lugejat, aga ka empiirilist autorit. Kaplinski minajutustaja nendibki: „Ka sina oled minu kujuteldav adressaat, inimene, kellest ma tegelikult suurt midagi ei tea, keda ma üldse ei tunne. Nagu kirjanikule enamasti ikka tema lugejad." (Kaplinski 2003: 5) Jutustaja on algusest peale teadlik sina olematusest (surmast), sinaga suhtlemisakti paratamatust monoloogilisusest (vastamise võimatusest, vt Kaplinski 2003: 144). Nõnda on Kaplinski sina kui hüpoteetilise, oletusliku vastuvõtja kõnetamine eelkäsitletuist selgemini vaadeldav ka apostroofsusena, st lüürilise pöördumisena, millele eksplitsiitset vastust enamasti ei kujutleta (vt Culler 2015: 237).

Ehkki ka Õnnepalu ei sulanda oma jutustusse eriti adressaadi häält, ei suhestu sinaga aktiivselt ega loo niisugust dialoogi nagu Mattheus, on tema kõnetlus ometi dialoogilisem kui Kaplinski oma, sest Paradiis kui koht suhestub mingil määral ühe teise kohaga ja nõnda tugevneb ka kõnetlusvõtte dialoogilisus. Kaplinski jutustuses on aga eksplitsiitse adressaadi häält väga vähe tajuda. See tuleneb esiteks sellest, et püütakse küll luua ühtne arusaam sinast kui isakujust, aga see kuju hajub paratamatult funktsioonide palju- 
susse: „[---] esiteks on ta raamatu (vähemalt formaalne) adressaat, kellele on kogu kirjutatu suunatud, teiseks kehastab ta „puuduvat Teist”, kellele saab projitseerida oma soove ja mõtteid, kolmandaks on ta samastumise-objekt, keda varjamatult ihaletakse, neljandaks toimib ta pihiisana, kellele saab rääkida ka oma varjatumaid tundeid, ja viimaks on ta lihtsalt mugav ettekääne, et rääkida iseendast ja oma tegemistest" (Tamm 2004: 108). Teiseks nõrgendab adressaadi vastuhäält kõnetluse rajanemine ennekõike omasuse ja võõruse pingel (isa kui bioloogiliselt lähedane isik vs. mitte kunagi kohatu ja tuntu), kolmandaks kõnetluse intiimsus, pihtimuslikkus. Kaplinski jutustuse sundimatu kulg tekitab tunde, et sellesse sekkumine, esitatud küsimustele ja kõhklustele konkreetselt vastamine, dialoogi tekkimine kaotaks intiimsele kõnetlusele üles ehitatud psühholoogilise pihtimuse efektiivsuse: tühistuks otsinguliste mõlgutuste mõte, perekonnalugu uurivate oletuste emotsionaalne mõju - ja tühistuks raamatu eksplitsiitse adressaadi kui jutustaja kujuteldava isa (re)konstruktsioon. Nii on see sina poole pöördumine sisuliselt nagu kõnelus jumalaga, kellelt ei oodata vastust, vaid ainult ärakuulamist ja vaimset ühendust (Kaplinski ütleb ise, et isa on talle olnud nagu „äraolev Jumal”, Kaplinski 2003: 14, vt ka Lestberg 2004; Hellerma 2004: 389). Nõnda on Kaplinski isakuju uurimiseks ja selle kaudu iseenda analüüsiks loodud adressaadi kandvaim roll olla otsekui vaikiv pihiisa - või kerge vastuvõtja, nagu määratles Õnnepalu oma adressaati.

\section{Lõpetuseks}

Kõigi kolme artiklis käsitletud teose ülesehitust ja laadi ning neis ilmnevaid eneseavaldusi on mõjutanud konkreetsele adressaadile suunatus, minajutustaja suhestumine ja (kaudne) suhtlemine sinaga. See mõju ilmneb aga erinevalt. „Paradiisi” lugu suunab mälestuste ja ruumi/maastike narratiivne korrastamine: „[---] et jutustada Sulle kõike seda, mis oli. Siin. Aga siis.” (Õnnepalu 2009b: 7) Õnnepalu minajutustaja annab üha tunnistusi oma adressaadi meeleshoidmisest, ent temaga aktiivne suhestumine jääb ennekõike krüptiliste fraaside tasemele. Üksnes harva avanevad adressaadi hääl ja põgusad seisukohad (nt niisugustes lausetes nagu „Ma tean, Sa ütled, et detsembris polegi ju pime. Ja täna on mul kerge Sinuga nõus olla. Sul on sagedamini õigus, kui Sa aimatagi oskad, kuigi mitte alati siis, kui Sa arvad, et on." (Õnnepalu 2009b: 10)), valdavalt aga on kõnetatav sina jäetud passiivseks kuulajaks, „kerge vastuvõtja” rolli. Seevastu „India armastuse” minajutustaja pöördub sina poole aktiivse suhtluse eesmärgil, adressaadi vastukaja on siin-seal suunanud teose temaatilist kulgu ja tonaalsust ning sinaga suhestumine toetab ühtlasi eneseanalüüsi, jutustava mina emotsionaalset ja vaimset avardumist. Kaplinski püüab raamatus erinevalt Õnnepalu ja Mattheuse teostest alles loo käigus luua arusaama jutustamisel silmas peetud vastuvõtjast, toetudes erinevatele dokumentaalsetele materjalidele, ning teoses üksnes hillitsetult kajastuv adressaadi hääl kuulub ettekujutusel põhinevale isakujule. Seetõttu ei kujutata „Isale” struktuuri ja laadi mõjutavat suhtlemist niivõrd vahetu kontaktina nagu „Paradiisis” ja „India armastuses”, kuivõrd algusest peale on kõnetluse tunnusena esil tugev oletuslikkus, kujuteldavus. Ometi on just 
„Isale” märksa jõulisem suhtluse otsimine, ärajäänud vestluste kompenseerimine, ehkki kõnetlus on suures osas monoloogilise pihtimuse raam.

Kuivõrd kõik kolm teost on autobiograafilised, on ootuspärane, et tegeliku autori empiiriline teadvus ilmneb jutustuse sees vastavuses tegelikkusega. Ometi ei ole sugugi neis kõigis esiplaanil omaeluloolise teksti tavaline tunnus: jutustaja mina eristamine ja avamine näiteks mitmesuguste identiteeti selgitavate kategooriate (põlvnemisest ja rahvusest kuni kultuurilise kuuluvuse ja poliitiliste vaadeteni) ning võtetega (vt Smith, Watson 2010: 38). Seegi oleneb kõnetlusvõtte sihist, sest igas käsitletud teoses on rõhu all erinev, just tekstisisese adressaadi valikust sõltuv aspekt. Enim jutustab Kaplinski oma põlvnemise ja perekonna lugu, minajutustaja otsib oma identiteeti puuduoleva isakuju kaudu. Ent Õnnepalu sisuliselt samuti ühest punktist tagasivaatav teos, mille adressaadiks on ühe teise omailma subjekt, avab minajutustajat hoopis väga konkreetselt koha ja sealsete inimestega seotud lugude kaudu. Armsama poole pöörduv jutustaja Mattheuse teoses aga rajab oma kirja vormis kõnetlused sisemistele otsingutele, enesetunnetuse, emotsioonide ja oma olemuse analüüsile ning on paljuski suunatud hoopis tulevikuväljavaadetele (armsama juurde tagasi jõudes eesootavale). Rõhuasetuse erinevusega on tugevalt seotud ka see, millise mina-avalduse teenistuses on iga käesolevas artiklis vaadeldud kõnetlusvõte. Õnnepalu esitab sina poole pöördudes ennekõike jutustavat mina, Kaplinski vahendab ajaloolist mina (perekonna- ja kujunemisloo raames) ning Mattheuse minakuju võiks liigitada ideoloogiliseks, oma hoiakute ideelisi aluseid selgitavaks.

Võib öelda, et käsitletud kirjanduslikest kõnetlustest üleneb adressaadi vaatepunkti ja väärtusi arvestavaks vestluseks, selgesti esile tulevaks dialoogiliseks suhestumiseks üksnes „India armastus”. „Isale” on küll vormiliselt väga tugev kõnetlus, koguni kujuteldav vestlus, ent teadmine vastuhääle puudumisest kammitseb selle tasandi dialoogilisust, kus tegutsevad minajutustaja ja tema ettekujutatud isa, avades teose suunatuse mis tahes võimalikule adressaadile. „Paradiis” on nii üht kui teist, kõnetatavat sina ei ole kujutatud aktiivse vestluskaaslasena, kes mõnel teisel juhul võiks loos väljenduva suhestumise kaudu ka ise karakteriks kujuneda. Ent peale küllaltki tiheda vormilise pöördumise sina poole on Õnnepalu hillitsetud kujul põiminud oma teksti siiski ka üksikuid adressaadi mõttelisi küsimusi või seisukohti, mis viitavad kõnetatava sina subjektsusele. Nii või teisiti on kõikides teostes tekstisisene adressaat lisaks narratiivi struktureerimisele ka sisemise dialoogi teenistuses: kujuteldav Teine võimaldab endast lähtuva jutustuse arendada enesekriitiliseks peegelduseks.

Artikkel on seotud institutsionaalse uurimisprojektiga IUT22-2 „Kirjanduse formaalsed ja informaalsed võrgustikud kultuuriloo allikate põhjal" ning Eestiuuringute Tippkeskusega. 


\section{Kirjandus}

B u r d orf, Dieter 2017. The I and the others. Articulations of personality and communication structures in the lyric. - Journal of Literary Theory, kd 11, nr 1, lk 22-31.

Culler, Jonathan 2015. Theory of the Lyric. Cambridge-London: Harvard University Press.

Ha ug, Toomas 2010. Maailm ja maq. - T. Haug, Klassikute lahkumine. 25 kirjatööd. Tallinn: Eesti Keele Sihtasutus, lk 236-244.

Hellerma, Kärt 2004. Kaplinski, klaassepa poeg. - Keel ja Kirjandus, nr 5, lk 387-391.

Ka plin ski, Jaan 2003. Isale. Tallinn: Varrak.

Ka s e m a a, Andrus 2012. Kustutamatud õhtud. Tallinn: Tuum.

Kurvet-Kä o s a a r, Leena 2016. Euroopa-ihalusest taasiseseisvusperioodi autobiograafiates. - Methis. Studia humaniora Estonica, nr 17-18, lk 163-179.

Kurvet-Käosaar, Leena 2017. Enese ilmnemine/ilmutamine Viivi Luige romaanis „Varjuteater”. - Adressaadi dünaamika ja kirjanduse pingeväljad. Koost, toim L. Kurvet-Käosaar, Marin Laak. (Studia litteraria Estonica 18.) Tartu: Tartu Ülikooli Kirjastus, lk 36-55.

Lejeune, Philippe 2010. Autobiograafiline leping. - Methis. Studia humaniora Estonica, nr 5-6, lk 196-223.

Lestberg, Ly 2004. Jaan Kaplinski isa otsimas. - Eesti Päevaleht. Arkaadia 16. I, lk 13.

Lind s a lu, Elo 2006. [Raamatututvustus.] - Eesti Ekspress: Areen 2. VIII.

Martens, Lorna 2016. Framing an accusation in dialogue: Kafka's Letter to His Father and Sarraute's Childhood. - The European Journal of Life Writing, kd $\mathrm{V}, \mathrm{lk} 61-76$.

M a t th e u s, Ülo 2006. India armastus. Fragmendid kirjadest. Tallinn: Eesti Keele Sihtasutus.

Melts, Brita 2014. Paradiis - Tõnu Õnnepalu kirjanduslik omailm. - Keel ja Kirjandus, nr 7, lk 509-524.

N e i e r, Agnes 2014. Foto funktsioon fiktsioonis. Magistritöö. Tartu: Tartu Ülikool. https://dspace.ut.ee/handle/10062/42417 (27. VIII 2019).

P aw el ec, Dariusz 2017. „Possible communications” and the „possible addressee” in lyrical poetry. - Studia Philologica Universitatis Velikotarnovensis, kd 36, nr 1, lk 313-323.

Pilv, Aare 2004. Kaplinski - iseenese poeg. - Postimees 30. I, lk 19.

Raamatututvustus 2006. - Sirp 12. V, lk 19.

Salumets, Thomas 2016. Kujuneda sunnita. Mõtestades Jaan Kaplinskit. Tlk Kersti Unt. Tallinn: Varrak.

Sch mid, Wolf 2013. Narratee. - the living handbook of narratology 22. I / 3. X. http://www.lhn.uni-hamburg.de/article/narratee\# (3. III 2018).

S mith, Sidonie, W at s o n, Julia 2010. Reading Autobiography. A Guide for Interpreting Life Narratives. Second edition. Minneapolis-London: University of Minnesota Press.

T a live e, Elle-Mari, T ü ü r, Kadri 2012. Paradiis maa peal. Tõnu Õnnepalu „Paradiisist". - Looming, nr 9, lk 1295-1305.

T a m m, Marek 2004. Kuidas kirjutada oma elulugu? - Vikerkaar, nr 3, lk 104-108. 
Velsker, Mart 2010. Üksainus Paradiis. - Vikerkaar, nr 4-5, lk 172-176.

Õ n ne palu, Tõnu 2009a. Kevad ja suvi ja. Tallinn: Varrak.

Õ nne palu, Tõnu 2009b. Paradiis. Tallinn: Varrak.

Õnnepalu 2010 = Tõnu Õnnepalu kirjutas oma paradiisi raamatusse. Intervjueeris Riho Laurisaar. - Eesti Päevaleht. Laupäev: Kultuur 9. I, lk 1-3.

Brita Melts (snd 1984), PhD, ajakirja Keel ja Kirjandus toimetaja (Roosikrantsi 6, 10119 Tallinn), brita.melts@ut.ee

\section{Addressing “you" in the works of Tõnu Õnnepalu, Ülo Mattheus and Jaan Kaplinski}

Keywords: explicit addressee, the "you" character, autobiographical narrative, Jaan Kaplinski, Ülo Mattheus, Tõnu Õnnepalu

The article looks at how the storyteller's self-expression is directed to the secondperson addressee, using the example of three autobiographical works: these are Paradiis (Paradise, 2009) by Tõnu Õnnepalu, where the story of a fixed place and time is told to a young friend, Isale (To Father, 2003) by Jaan Kaplinski, seeking a dialogue with a father long dead and never met, and India armastus (The Love of India, 2006) by Ülo Mattheus, which consists of letters sent to the storyteller's beloved during the several months spent in religious asylum. The comparison of the three texts seeks to clarify the role of the (second-person) addressee in each book, the compositional and stylistic meaning of the "you", the possible influence of the storyteller's thinking of the addressee on his self-presentation, and the voice and views of the "you" possibly elicited by the rhetorical address.

In each book the storyteller relates differently to the "you". Õnnepalu's narrator keeps recurring to his memory of the addressee, yet there is no sign of active communication except some cryptic phrases. Mattheus's narrator, however, addresses the "you" for the purpose of active communication, while the response keeps guiding the thematic course and tonality of the work and the relationship supports the self-analysis of the narrating "I". In Kaplinski's case the whole story has been written to create, based on documentary material, an idea of the explicit addressee, whose quiet voice belongs to an imaginary father figure. Thus, unlike Õnnepalu and Mattheus, Kaplinski depicts the pivotal communication process not as direct contact but rather as something imaginary. Now, each of the above three ways of address supports a different kind of storytelling. Onnepalu addresses his "you" mainly from the position of a narrating "I", while Kaplinski mediates a historical "I" based on family and development history, and Mattheus's "I" could be classified as an ideological one, engaged in explaining the ideological foundations of his attitudes. Either way, all three texts use the second-person addressee not only for structuring the narrative but also for developing a dialogue: the imaginary "you" serves to amplify a self-based narrative into a self-critical reflection.

Brita Melts (b. 1984), PhD, journal Keel ja Kirjandus (Roosikrantsi 6, 10119 Tallinn), editor,brita.melts@ut.ee 